\title{
MEDIATION - CURRENT STATE OF USE IN THE REPUBLIC OF NORTH MACEDONIA
}

\author{
Faton Shabani \\ Facutly of Law, University of Tetova
}

\begin{abstract}
Mediation is a flexible, non-binding dispute resolution method in which a neutral (impartial) third party (mediator) helps two or more disputes to reach a voluntary, negotiated settlement of their disputes. Mediation, emerging strongly as an alternative method of dispute resolution (with the help of neutral third party), has made litigation today not to be treated as the only option for dispute resolution between individuals and businesses. As a means for resolving disputes it has found application especially in business, labor, family, insurance, consumer and construction disputes. The cost, speed and expertise of resolving disputes are some of the key factors that attract individuals, businesses, organizations but also state bodies and institutions to support and promote mediation in this era of globalization and life and activity exposed to the dynamics of contemporary developments. Added to this, however, is the acceptance in the vast majority of cases of dispute resolution reached by both parties to the dispute, but also the privacy and confidentiality of the resolution of their case. Despite the fact that mediation internationally has already been seriously established in the area of dispute resolution, in the Republic of North Macedonia, the legal framework and implementation in practice is at the forefront. For this reason, in addition to the empirical, descriptive and normative treatment, the author through the methods of analysis, synthesis and statistical method processes the official results of the Ministry of Justice to give a clear picture of the trends of the use of mediation in dispute resolution over a period of 5 years (2016-2020) in the Republic of North Macedonia.

KEYWORDS: Mediation; neutral; third party; legal framework; practice.
\end{abstract}

JEL: O17, P48, L84

\section{Introduction}

Alternative dispute resolution (ADR) is not a new phenomenon for dispute resolution, on the contrary, it was present even before the litigation was developed. Historically, the view has prevailed that the disputing parties are directly involved in the dispute and that it is in their interest to settle the dispute (Fazlia \& Shabani, 2019). Mediation as one of the most discussed alternative ways of resolving disputes is in fact a structured negotiation process where the parties in a dispute voluntarily meet to discuss their dispute with the help of an independent and accredited mediator. The mediator's role is to act as an independent and disinterested third party and encourage the parties to talk and to move towards a possible agreed settlement (Andrews, 2012). Mediation is a key form of ADR. Alternative here means an alternative to having a decision imposed by a judge in court. Mediation is a consensual process, based on self-determination that involves the participants in the dispute, together with their lawyers, advisers, or supporters, if they have any, meeting with a neutral third person. The mutual aim is to find a resolution to the dispute or problem that the participants face (Dinge \& Kelbie, 2013). Given the advantages of informality, speed and ability to take both parties' interests into account, it makes sense for mediation to replace legal solutions where possible (Liebermann, 2000). In addition, one more reason that pushes the parties to decide to choose mediation to resolve their disputed issues is the confidentiality that this method offers. The scope of confidentiality in mediation ultimately revolves around the tension between (1) private agreements express or implied to keep information private and secret and (2) the traditional appetite for disclosure and transparency in legal proceedings. As such confidentiality refers to something known only to a limited few and not publicly disseminated and is indicative of something private, secret, intimate and/or hidden (Rovine, 2009). Parties usually turn to mediation when they have run out of better ways to resolve a dispute. They may have concluded that litigating may produce a disappointing result, consuming a disproportionate amount of time, energy and money. They have likely reached a point where negotiating without help is not taking them forward. Communication has become blocked or even broken down entirely (Macmillan, 2012). That's why Amy L. Smith and David R. Smock have found widespread support in their finding that mediation is an art form, incorporating intuition, subtlety, and vision (Smith \& Smock, 2008). Lukasz Rozdeiczer and Alejandro Alvarez de la Campa, on the other hand, focus on treating mediation as science and art. The science of mediation consists of many academic disciplines, such as: legal theory, game theory, economics, and psychology. The greatest challenge in introducing mediation is the art of applying this broad and interdisciplinary body of knowledge to the dispute resolution system in a given country and later to a particular dispute (Rozdeiczer \& Campa, 2006). By voluntary participating in the mediation process, fear and 
anxiety of parties are greatly reduced. During mediation parties are encouraged to identify and explore options to resolve their dispute. The mediator is a neutral observer who is not emotionally related either to disputing parties or to the subject matter and can get through to the heart of the matter in order to open up discussions as to how to resolve the dispute. For this reason, the mediator cannot make a decision regarding the outcome and supports the parties to reach their own agreement. One of the most distinguishing features of mediation, compared to other processes, is that $\mathrm{i}$ tends to involve the disputing parties directly in the resolution of their disputes. Above all, the growing interest in mediation reflected the idea of democratizing the judiciary and removing the problems of the community from the exclusive control of the courts, lawyers and other 'experts'. In the vast majority of forms of mediation, disputing parties sit at the negotiating table with or without their attorneys, and participate fully in developing solution to their problems (Frenkel \& Stark, 2018). Rather than resort to litigation where there is a clear winner and a clear loser, the mediator strives to guide the disputing parties to work toward a resolution that is agreeable to everyone. In this way the mediator evens out the playing field and everyone walks away a winner in some respect. When mediation is successful, the parties leave the process feeling validated and satisfied.

The past thirty years have seen an explosive increase in the use of meditation. Originally closed to specific, such as labour relations, mediation today is the process that applies to almost all types of disputes or transactions that can be found in society - from small claims to those worth millions; from family, social, education, to environmental, public policy and interstate affairs (Frenkel \& Stark, 2018). Admissibility refers to the willingness of disputing parties to welcome, accept, tolerate or at least not object the involvment of a third party that assists them in resolving disputes. This simply means that the parties are willing to listen ad seriously consider his suggestions regarding the process in order to resolve their differences (Moore, 2014). Mediating parties nearly always have the choice of continuing the dialogue or withdrawing. Importantly, the mediator has no power to impose a solution upon the parties, although [in some cases] a mediator has the power to propose solutions. The resolution of the dispute can only result from an agreement between the parties. This is why a party cannot be blamed for not reaching an amicable settlement through mediation (Stipanowich, 2004). If both parties agree to observe the outcome, their signature to the agreement makes it legally binding and can be enforced in the same way as adjudicated/arbitrated decisions.

\section{Measures taken by North Macedonia to establish mediation as a successful alternative dispute resolution}

Despite the existence of separate legislation on mediation (Law on Mediation, 2006) and the establishment of the Mediation Chamber, the use of mediation in our Macedonian practice, however, has been addressing serious challenges, instead of making any progress. Analyzes showed that it did not achieve the goal it set, i.e. it did not come up with an important tool, it had very little presence and efficiency. the Government has been analyzing the causes of these conditions for a long time, while also researching and analyzing how and with that improvements the conditions can be improved. In fact, in the justification provided by the Ministry of Justice for the need to adopt the new law on mediation, it provided the data from Registry of Evidence of Mediation Procedures, which provide evidence that the number of mediations registered as of June 2013 was only 22, despite the existence of 156 mediators registered at that time. In order to improve this situation regarding the use of mediation, several steps were taken.

First, the new adopted Law on Mediation (2013) sets out the obligation for the court to instruct the parties to resolve the dispute through mediation at each stage during the course of the first instance litigation: "The court, during the course of the first instance proceedings, advises the parties to settle the dispute in the mediation procedure and notes this in the minutes of the hearing. The judge, with the consent of the parties to the dispute, at any stage of the judicial procedure, may terminate the proceedings and instruct the parties to mediation" (Article 29, Law on Mediation, 2013).

Second, by adopting the Law on Changing and Amending the Law on Contentious Procedure a change of Article 461 has been made with Article 47 of the consolidated text of the Law on Contentious Procedure (2005) which reads as follows: "In the commercial disputes, when it comes to financial claim the value of which does not surpass a sum of 1.000.000 denars and upon which the procedure is initiated with a complaint in front of a court, the parties are obliged, before submitting the complaint, to try to solve the dispute by mediation. When filing the complaint, the plaintiff is obliged to submit a proof issued by a mediator that the attempt to solve the dispute with mediation has failed. The complaint to which the proof stated in paragraph (2) of this Article is not attached will be rejected by the court". This implies that, despite the fact that the EU and most of the states have chosen to initially opt for a voluntary approach to mediation, North Macedonia, in order to promote the use of mediation, has recently introduced mandatory mediation in cases of certain monetary disputes.

Third, alternative dispute resolution is also supported by the Company Law (2004) (Article 41), which stipulates that a companies, being a community of private individuals, i.e. members or shareholders of the company may agree to initially attempt to resolve disputes related to the company agreement or charter by settlement including mediation and negotiation. If, however, the disputes may not be resolved by means of settlement, members or shareholders may, if they so agree, resolve the disputes by means of arbitration. The legislator to prioritize and promote such dispute resolutio opportunities by members and shareholders of business entities outside state courts has been determined so that, as far as possible, their dispute within the entity are 
resolved in good faith and in an exttrajudicial manner by third-party help, all in the spirit of a market economy (Fazlia \& Shabani, 2019). According to the Government, these law solutions make major and substantial reforms to the justice system, a reform that will help the mediation gain its visibility and presence in resolving disputes between the business entities, but also a reform that will relieve the courts of the sheer number of cases that will primarily help entities, citizens and legal entities.

Fourth, the great novelty is the anticipation of a new role of mediator, with a dominant characteristic of mediator quality, expertise, and ability. He as a central figure in the process with his credibility should become synonymous with recognizing mediation as an efficient, effective and effective legal tool and thereby give great visibility to mediation. As a result, mediator will be able to become a physically fit person who passes the mediation exam and is gained a license. The issued license is valid for five years and may be extended or revoked depending on the results of the evaluation of the mediator's quality of work (Article 46, Law on Mediation, 2013).

Fifth, due to the development of mediation, the Government envisages part of the mediation costs: where the mediation procedure is not mandatory under the separate law, if it was conducted prior to the commencement of court proceedings, one of the parties to the mediation procedure is a natural person, and the mediator reported the mediation case as completed in the Mediation Procedure Records Register, and presented a cost estimate on a prescribed form for the costs of the mediation procedure and the mediator's award. The beneficiary of the subsidy is the mediator, while the necessary funds for subsidizing the mediation are provided and paid annually by the Ministry of Justice within its own budget (Article 28, Law on Mediation, 2013).

Sixth, a new body is introduced which has a central role in mediation, namely the Board for Providing, Monitoring and Assessing the Quality of Mediationrelated Activities. The Board is composed of 10 members appointed by the Government (Article 57, Law on Mediation, 2013). The Board, on the basis of the principle of autonomy and expertise, inter alia, performs the following: a) establishes the eligibility requirements for a completed mediator training certificate, b) forms the basis of questions for taking a mediator exam; c) determines exam sessions and the manner of passing the exam for mediators, d) organizes and conducts the exam and issues exam certificates, e) issues mediator licenses and mediator trainers, f) accredits mediator training programs (Article 59, Law on Mediation, 2013).

Seventh, the Ministry of Justice created a Mediation Promotion Plan, consisting of public promotion, campaigns in national courts, training for civil servants, media campaigns and the like. The Plan also contained guidelines to stimulate the frequent use of mediation by public bodies by encouraging these bodies to resolve disputed situations between them through mediation.

Eighth, the next important step was the establishment of the Mediation Center within the Association of
Chambers of Commerce of North Macedonia in 2019. This center was opened following the example of European countries, where there are mediation centers within the chambers to promote the principle of access to justice for all, as well as to meet international standards. The Center aims to regularly organize lectures, presentations, workshops and trainings for business community representatives who wish to apply mediation as a dispute resolution procedure. Moreover, the Center is intended to represents official place where the mediator will introduce the representatives of the public and private sectors, as well as the citizens with the mediation.

Finally, the signing of the United Nations Convention on International Settlement Agreements Resulting from Mediation (2018) by North Macedonia is an important step. The Convention was signed on August 7, 2019 in Singapore. So far, agreements resolving international trade disputes that were reached through mediation have no safeguards and guarantees for cross-border enforcement. The Convention, known as the Singapore Mediation Convention, will provide for enforcement and compliance with mediation agreements, providing companies and international investors with greater legal certainty that will increase international trade. 46 states signed it. In accordance with Article 14 (1), the Convention shall enter into force six months after the deposit of the third instrument of ratification, acceptance, approval or accession.

\section{Current state of use of mediation in North Macedonia}

An important step in the concretization of the mediation institute and its promotion for the purpose of its wider and more frequent use was its detailed definition in the Law on Mediation. Mediation is defined as any mediation, regardless of its name, the resolution of dispute in the mediation process in which the parties to the dispute are allow it to resolve the dispute by negotiation, peacefully using one or more licensed mediators to achieve mutually acceptable solution expressed in the form of a written agreement (Article 2, Law on Mediation, 2013). It applies in particular to property, family, labor, commercial, consumer, insurance, education, environmental, discrimination, and other disputes where mediation corresponds to the nature of the disputed relationship and can help to dismiss them (Article 1, Law on Mediation, 2013).

Within the framework of the measures taken by the Government is the publication of the register of licensed mediators on the official website of the Ministry of Justice. This step was taken in order to make the persons who put their professional mediation service at the disposal of the interested parties as transparent as possible. The register in question contains the name and surname of the broker, the address of residence, contact information (telephone number and e-mail address), license number, license issuance date and license validity date. As of February 2020, the list contains 45 licensed active mediators. 
In North Macedonia, unfortunately, there is no electronic database or website where information on the mediation procedures performed will be continuously presented, published and updated. The only way to access such information is by direct inspection of the Registry for Identification of Mediation Procedures where disputes that have been resolved through mediation are identified. This register is managed by the Ministry of Justice, while its data is populated by mediators who are legally required (Article 21, Law on Mediation, 2013) to submit each proceeding, stating whether the procedure is completed by reaching an agreement between the parties to the dispute or failed and was completed without reaching an agreement.

Mediators love to speak of their settlements. They prove their success as mediators. Some boast of settlement rates in terms of percentage of cases settled $70 \%$... $80 \%$... even $95 \%$ ! This business of competitive rating is not entirely vacuous. After all, the aim of the mediation is to achieve a settlement (Macmillan, 2012). Based on the Registry for Identification of Mediation Procedures, submitted by licensed mediators, the number of disputes settled through mediation from 2016 (as of now there is current evidence that relies on Law on Mediation) to 2019 indicates that there is an increasing interest in using mediation as a dispute resolution tool.

Table 1 presents the data showing that out of the total number of cases treated in this study, i.e. 1930 cases, there were a total of $655(34.5 \%)$ cases completed without agreement and $1265(65.5 \%)$ cases completed by agreement. Relevant data are also presented graphically in graph number 1.

Table 1 - Disputes completed by and without agreement

\begin{tabular}{|r|r|r|r|r|r|}
\hline & & & & \multicolumn{2}{|c|}{$\begin{array}{c}\text { Cumulative } \\
\text { Percent }\end{array}$} \\
\hline \multirow{3}{*}{ Valid } & No agreement & 665 & 34.5 & 34.5 & 34.5 \\
\cline { 2 - 6 } & By agreement & 1265 & 65.5 & 65.5 & 100.0 \\
\cline { 2 - 6 } & Total & 1930 & 100.0 & 100.0 & \\
\hline
\end{tabular}

Source: Ministry of Justice (Republic of North Macedonia)

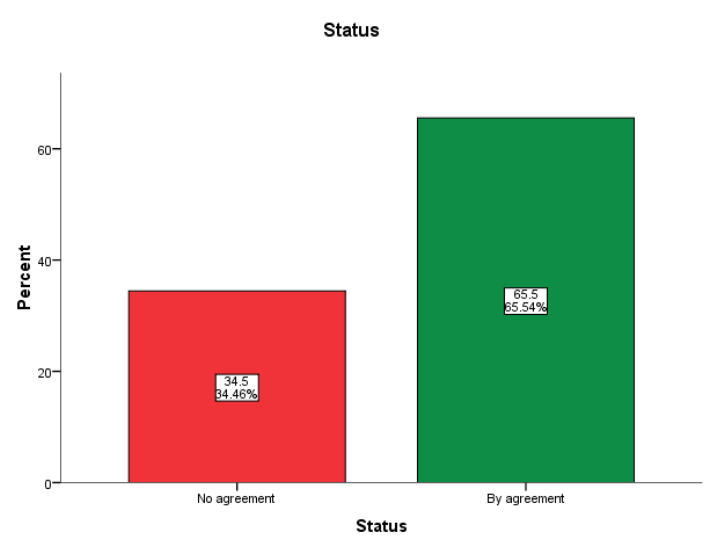

Chart 1 - Disputes completed by and without agreement

Table 2 presents data showing the differences of all types of disputes from 2016 to 2020 , by their closure status by agreement and without agreement. In 2016 there were 38 disputes completed without agreement, while 26 disputes ended by agreement of 64 disputes in total. Unlike, in 2017 there were 80 disputes completed without agreement and higher number of disputes completed by agreement - 902. In 2018 there were 156 disputes completed without agreement and 137 completed by agreement of 293 disputes in total. In 2019 there were 156 disputes completed without agreement and 72 disputes completed by agreement, out of 231 disputes. In 2020 there were 232 cases completed by agreement and 128 disputes without agreement, out of a total of 360 cases.

Differences between the years of disputes by their status of the final epilogue result in statistically significant differences $\mathrm{p}<0.01$. The data in Table 2 are also presented graphically in Charts 2-7. 
Table 2 - Data of differences of all types of disputes from 2016 to 2020

\begin{tabular}{|c|l|r|r|r|}
\hline \multicolumn{2}{|c|}{} & \multicolumn{2}{|c|}{ Status } & \multirow{2}{*}{} \\
\cline { 3 - 6 } \multicolumn{2}{|c|}{} & \multicolumn{2}{|c|}{ No agreement } & \multicolumn{2}{|c|}{ By agreement } & \multicolumn{2}{|c|}{ Total } \\
\hline \multirow{4}{*}{ Year } & 2016 & 38 & 26 & 64 \\
\cline { 2 - 6 } & 2017 & 80 & 902 & 982 \\
\cline { 2 - 6 } & 2018 & 156 & 137 & 293 \\
\cline { 2 - 6 } & 2019 & 159 & 72 & 231 \\
\cline { 2 - 6 } & 2020 & 232 & 128 & 360 \\
\hline Total & & 665 & 1265 & 1930 \\
\hline
\end{tabular}

Source: Ministry of Justice (Republic of North Macedonia)

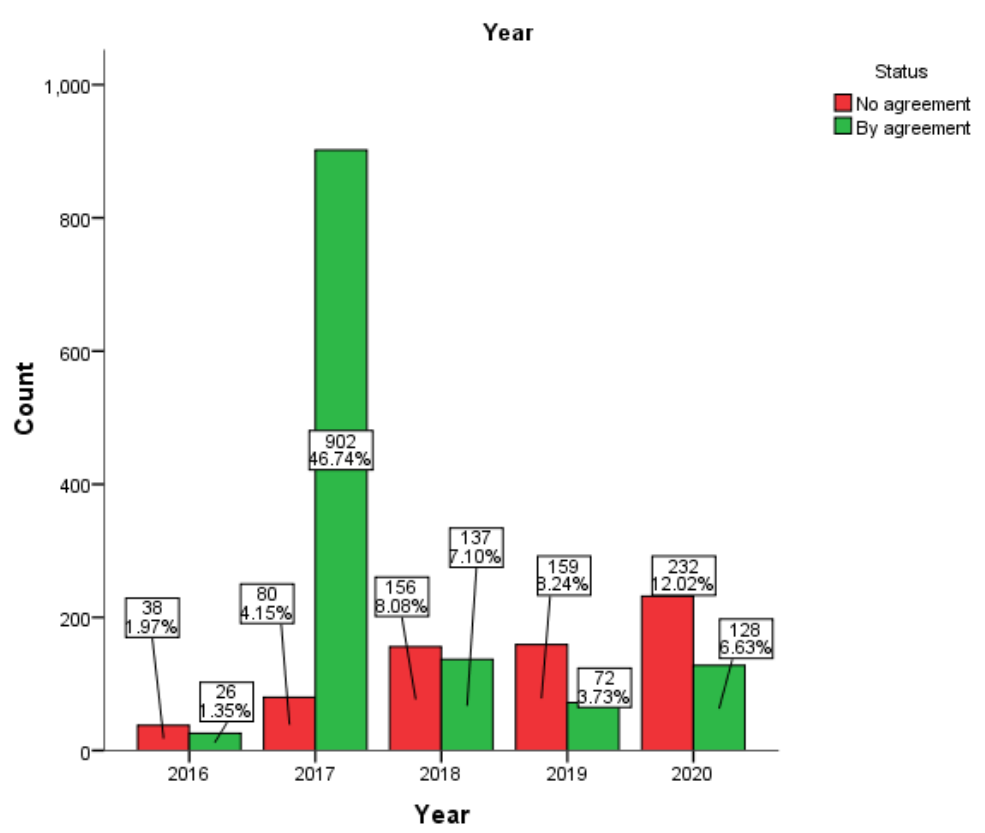

Chart 2 - Disputes completed through mediation over the years 


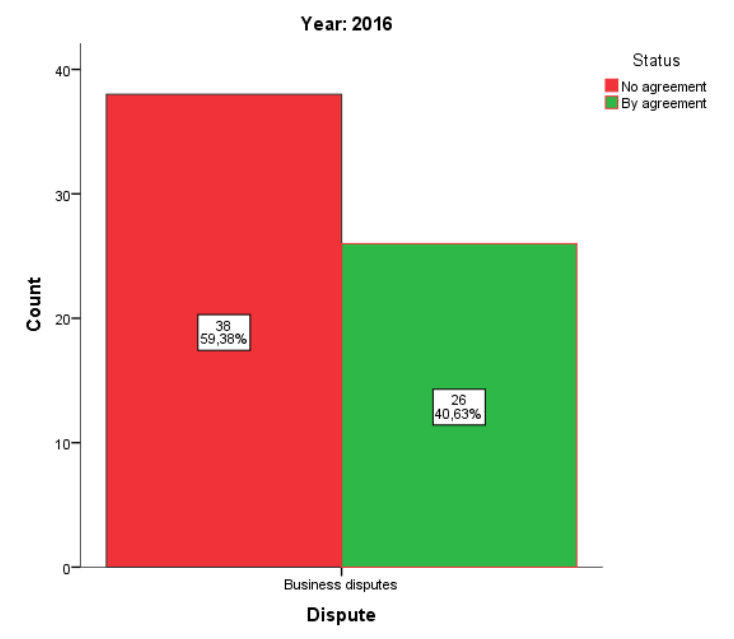

Chart 3 - Disputes completed in 2016

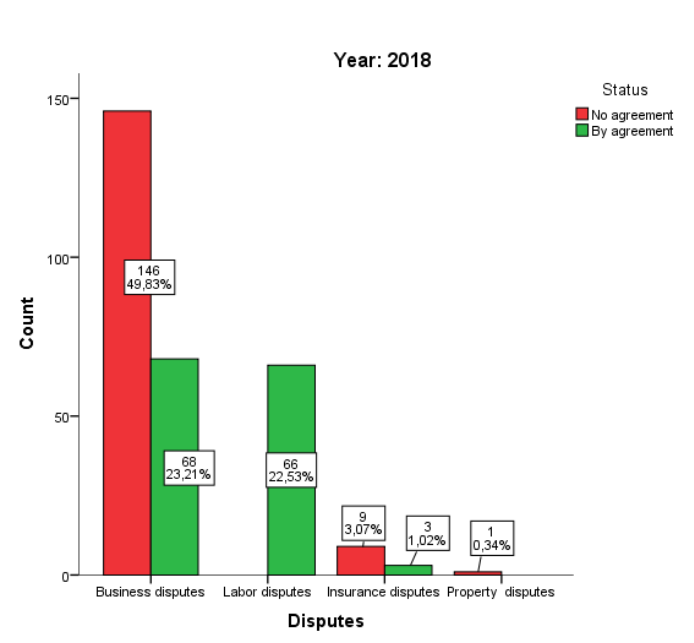

Chart 5 - Disputes completed in 2018

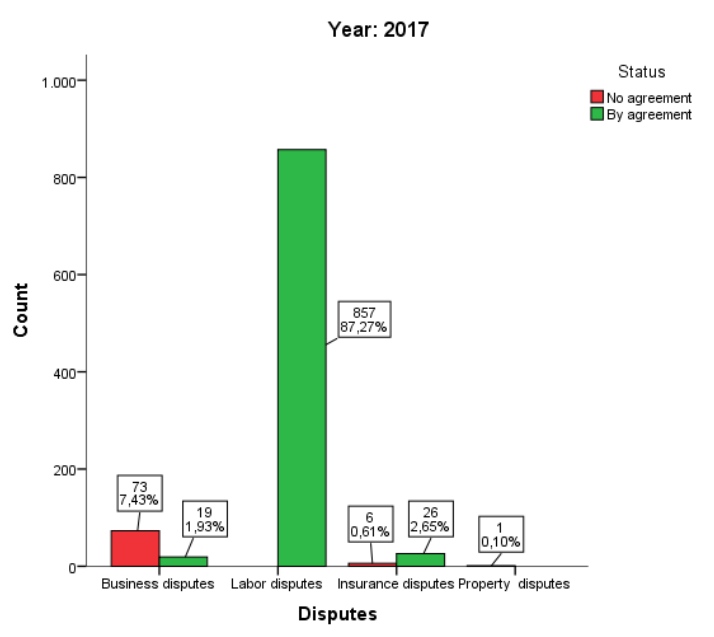

Chart 4 - Disputes completed in 2017

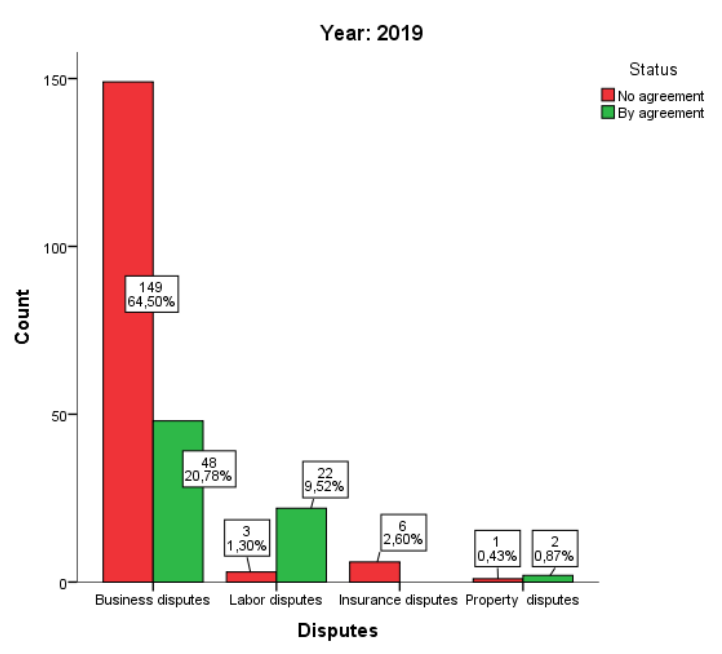

Chart 6 - Disputes completed in 2019 


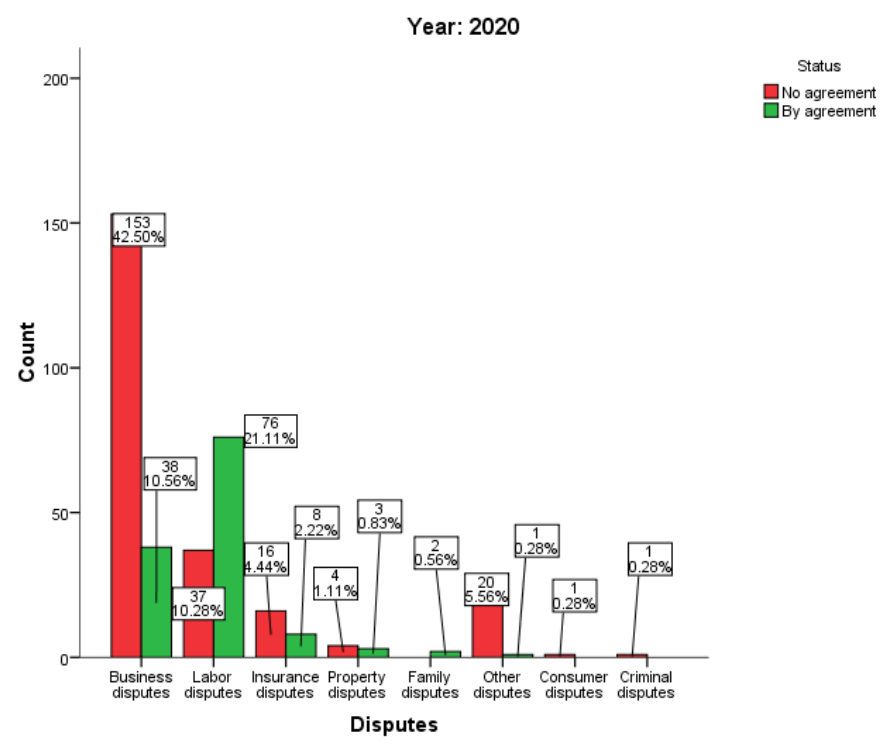

Chart 7 - Disputes completed in 2020

Table 3 presents the data showing the differences reported by licensed mediators about conducted mediation procedures, of which 559 cases ended without agreement and 199 cases ended by agreement, from 758 cases in total.

- 559 business cases ended without agreement and 199 cases by agreement, from 758 cases in total;

- 40 labor cases ended without agreement and 1021 cases by agreement, from 1061 cases in total;

- 37 insurance cases ended without agreement and $37 \mathrm{c}$ ases by agreement, from 74 cases in total;

- 7 property cases ended without agreement and 5 cases by agreement, from 12 cases in total;
- $\quad$ all 2 family cases ended by agreement;

- 1 consumator case ended without agreement, from 1 case in total;

- 1 criminal case ended without agreement, from 1 case in total;

- 20 from the category 'other' ended without agreement and 1 by agreement, from 21 cases in total.

Statistical differences of disputes types and settlement status were statistically significant at sig $=0.00$. The difference in the status of the epilogue of resolving disputes of various natures is more pronounced in labor disputes which are distinguished for settlement by agreement, while in business disputes the dominance of settlement without agreement is observed. The same data is shown graphically in Chart 8 .

Table 3 - Data from mediation procedures in business, labor, insurance, property, family, consumer, criminal and other disputes

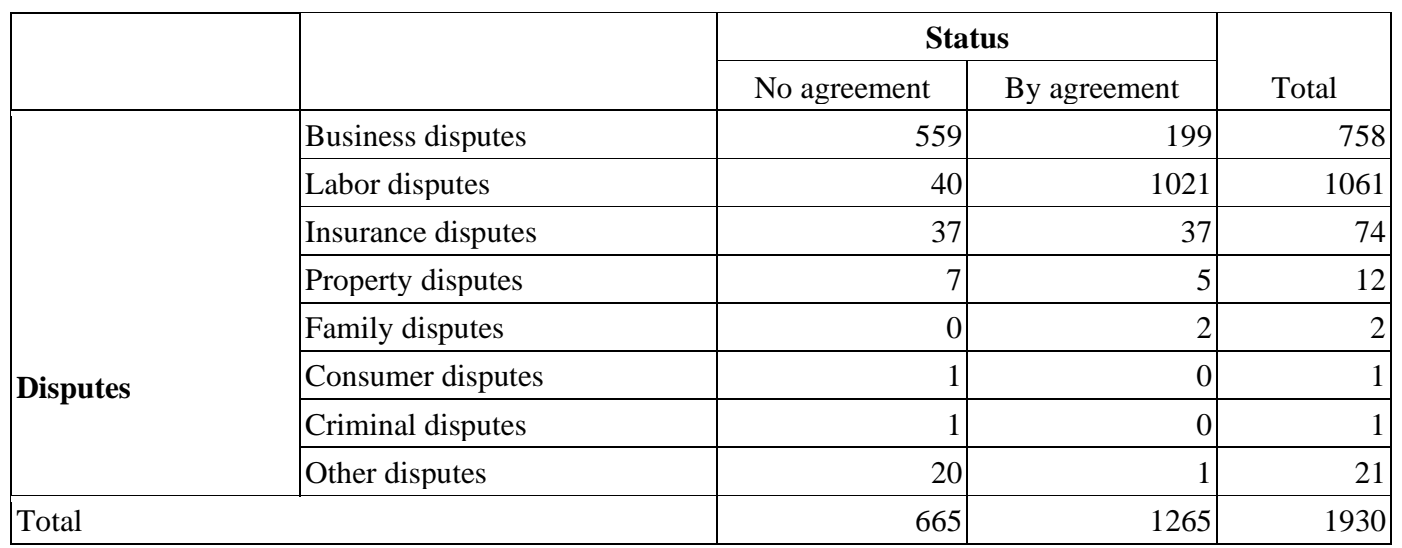

Source: Ministry of Justice (Republic of North Macedonia) 


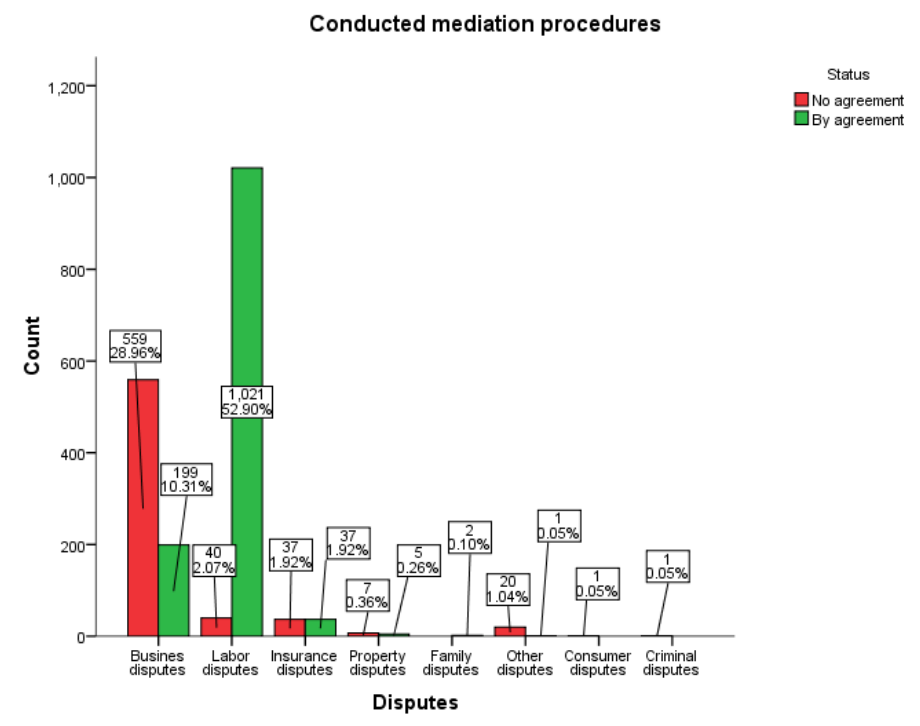

Chart 8 - Mediation procedures in business, labor, insurance, property, family, consumer, criminal and other disputes

Finally, Table 4 shows the differences of all types of disputes out of 1930 disputes, from 2016 to 2020 , showing that in 2016 there were only 64 disputes, all based on business matters. In 2017 there were 92 business, 857 labor, 32 insurance and 1 property dispute. In 2018 there were 214 business, 66 labor, 12 insurance and 1 property dispute. In 2019 there were 197 business, 25 labor, 6 insurance and 3 property disputes. In 2020 there were 191 business, 113 labor, 24 insurance, 7 property, 2 family, 1 consumer, 1 criminal and 21 other disputes These differences were statistically significant at $\operatorname{sig}=0.00$.

Table 4 - Differences of all types of disputes from 2016 to 2020

\begin{tabular}{|c|c|c|c|c|c|}
\hline & & & & Count & Column N \% \\
\hline \multirow{24}{*}{ Year } & \multirow{4}{*}{2016} & \multirow{4}{*}{ Disputes } & Business disputes & 64 & $100,00 \%$ \\
\hline & & & Labor disputes & 0 & $0,00 \%$ \\
\hline & & & Insurance disputes & 0 & $0,00 \%$ \\
\hline & & & Property disputes & 0 & $0,00 \%$ \\
\hline & \multirow{4}{*}{2017} & \multirow{4}{*}{ Disputes } & Business disputes & 92 & $9,37 \%$ \\
\hline & & & Labor disputes & 857 & $87,27 \%$ \\
\hline & & & Insurance disputes & 32 & $3,26 \%$ \\
\hline & & & Property disputes & 1 & $0,10 \%$ \\
\hline & \multirow{4}{*}{2018} & \multirow{4}{*}{ Disputes } & Business disputes & 214 & $73,04 \%$ \\
\hline & & & Labor disputes & 66 & $22,53 \%$ \\
\hline & & & Insurance disputes & 12 & $4,10 \%$ \\
\hline & & & Property disputes & 1 & $0,34 \%$ \\
\hline & \multirow{4}{*}{2019} & \multirow{4}{*}{ Disputes } & Business disputes & 197 & $85,28 \%$ \\
\hline & & & Labor disputes & 25 & $10,82 \%$ \\
\hline & & & Insurance disputes & 6 & $2,60 \%$ \\
\hline & & & Property disputes & 3 & $1,30 \%$ \\
\hline & \multirow{8}{*}{2020} & \multirow{8}{*}{ Disputes } & Business disputes & 191 & $53,06 \%$ \\
\hline & & & Labor disputes & 113 & $31,39 \%$ \\
\hline & & & Insurance disputes & 24 & $6,67 \%$ \\
\hline & & & Property disputes & 7 & $1,94 \%$ \\
\hline & & & Family disputes & 2 & $0,56 \%$ \\
\hline & & & Consumer disputes & 1 & $0,28 \%$ \\
\hline & & & Criminal disputes & 1 & $0,28 \%$ \\
\hline & & & Other disputes & 21 & $5,83 \%$ \\
\hline
\end{tabular}

Source: Ministry of Justice (Republic of North Macedonia) 


\section{Conclusion}

Mediation participation as an alternative method of resolving disputes in the Republic of North Macedonia, according to official data from the Ministry of Justice, continues to remain low. The fact of longevity in Macedonian practice has undoubtedly contributed to such a state of mediation. More specifically, this method of resolving disputes has not been implemented for more than 2 decades, while only since 2006 it is regulated by a special law. In order to increase the level of use of mediation and in the spirit of supporting and promoting mediation, the Government of North Macedonia has taken several concrete actions: adoption of the new law on mediation, amending and supplementing the law in force on the contentious procedure and the law on companies in favor of mediation, remodeling the role of mediator, ensuring the coverage of mediation costs by the Government, introduction of a new body (the Board for Providing, Monitoring and Assessing the Quality of Mediation-related Activities), and the creation of the Mediation promotion Plan. Statistics show that 2016, when the register of implemented mediation procedures is maintained, marks the year with the lowest number of mediation procedures, while 2017 with the highest number compared to other years. Statistics show that 2016, when the register of implemented mediation procedures is maintained, marks the year with the lowest number of mediation procedures, while 2017 with the highest number compared to other years. From the point of view of types of disputes, labor disputes lead, followed immediately by business disputes, insurance disputes and property disputes. It is expected that criminal disputes will be at the bottom of the list, as disputes less suitable for resolution through mediation.

\section{References}

Andrews, Neil. (2012). The Three Paths of Justice: Court Proceedings, Arbitration and Mediation in England, London: Springer.

Beer, Jennifer E., Caroline C. Packard. (2012). The Mediator's Handbook (Revised and Expanded $4^{\text {th }}$ edition), New Society Publishers.

Colatrella, Michael T., Anthony P. Picchioni. (2008). Mediation: Skills and Techniques, LexisNexis.

Company Law, Official Gazette of Republic of North Macedonia, No. 28/2004, 84/2005, 25/2007, 87/2008, $42 / 2010, \quad 48 / 2010, \quad 24 / 2011, \quad 166 / 2012, \quad 70 / 2013$, $119 / 2013, \quad 187 / 2013, \quad 38 / 2014,41 / 2014, \quad 138 / 2014$, $88 / 2015, \quad 192 / 2015, \quad 06 / 2016 . \quad 61 / 2016, \quad 64 / 2018$, $120 / 2018$.

Dingle, Jonathan, Judith Kelbie. (2013). The Mediation Handbook (2013-2014), London: London School of Mediation.
Doneff, Andrea, Abraham P. Ordover. (2014). Alternatives to Litigation Mediation, Arbitration, and the Art of Dispute Resolution ( $3^{\text {rd }}$ edition), New York: Wolters Kluwer.

Duryee, Lynn, Matt White. (2012). Mastering Mediation: 50 Essential Tools for the Advanced Practitioner, Thomson Reuters Westlaw.

Engel, Antonia, Benedikt Korf. (2005). Negotiation and mediation techniques for natural resource management, Food and Agriculture Organization of the United Nations, Rome.

Fazlia, Drita M., Faton Z. Shabani. (2019) Zgjidhja jashtëgjyqësore e kontesteve. Tetovë.

Frenkel, Douglas N., James H. Stark. (2018). The Practice of Mediation (3rd edition). New York: Wolters Kluwer.

Golann, Dwight, Jay Folberg. (2016). Mediation: the Roles of Advocate and Neutral ( $3^{\text {rd }}$ edition), New York: Wolters Kluwer.

Isaacson, Kathy, Heidi Ricci, Stephen W. Littlejohn. (2020). Mediation: Empowerment in Conflict Management (3rd edition), Illinois: Waveland Press, Inc.

Law on Civil Procedure, Official Gazette of Republic of North Macedonia, No. 79/2005, 110/2008, 83/2009, 116/2010, 124/2015.

Law on Mediation, Official Gazette of Republic of North Macedonia, No. 188/2013, 148/2015, 192/2015, 55/2016.

Macmillan, Rory. (2012). A Practical Guide for Mediators, http://www.macmillankeck.pro/media/pdf/A\%20Practica $1 \% 20$ Guide $\% 20$ for\%20Mediators.pdf [10.02.2020].

Menkel-Meadow, Carrie J. , Lela Porter-Love, Andrea KupferSchneider. (2020). Mediation: Practice, Policy, and Ethics, New York: Wolters Kluwer.

Moore, Christopher W. (2014). The Mediation Process: Practical Strategies for Resolving Conflict (4th edition). San Francisco: Jossey-Bass.

Papa, Marta J. (2008). Business Mediation: A Better Way To Resolve Workplace Conflict, https://www.mediate.com/articles/papaM1.cfm [07.11.2020].

Relis, Tamara. (2009). Perceptions in Litigation and Mediation: Lawyers, Defendants, Plaintiffs, and Gendered Parties, Cambridge: Combridge University Press.

Rovine, Arthur W. (editor). (2009). Contemporary Issues in International Arbitration and Mediation (The Fordham Papers 2008), Leiden: Martinus Nijhoff Publishers.

Rozdeiczer, Lukasz, Alejandro Alvarez de la Campa. (2006). Alternative Dispute Resolution Manual: Implementing Commercial Mediation, The World Bank Group.

Shabani, Faton Z. (2018). E drejta afariste ndërkombëtare. Tetovë: Universiteti i Tetovës.

Smith, Amy L., David R. Smock. (2008). Managing a Mediation Process, Washington, D.C.: United States Institute of Peace.

Stipanowich, Thomas (2004). Why Businesses need Mediation, https://papers.ssrn.com/sol3/papers.cfm?abstract_id=242 3097 [12.03.2021].

United Nations Convention on International Settlement Agreements Resulting from Mediation (2018). 
Faton Shabani, Ph.D is Associate Professor at Faculty of Law, University of Tetova, situated in Tetovo, Republic of North Macedonia. He is author of four textbooks. He is also an author and co-author of more than 60 refereed papers in scientific journals, and conference proceedings books. Current research interests: business law, contract law, intellectual property, consumer protection, competition law, and international business law.E-mail: faton.shabani@unite.edu.mk. 